Dr. Bindu N. Lohani

Former Vice President, Asian Development Bank (ADB)

Manila, Philippines

With an objective to highlight the prominent Nepali personalities who have played important roles in major donor agency, Asian Development Bank (ADB), HYDRO Nepal Journal considers it appropriate to underline the profile of Dr. Bindu N. Lohani to its readers.

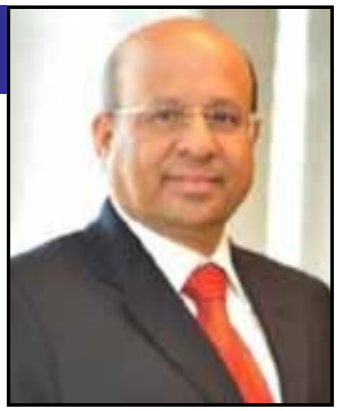

\section{Educational Background}

$\mathrm{D}^{1}$ Lohani holds a Bachelor's Degree in Civil Engineering, and a Masters degree (water and waste management) and Doctoral degree in Environmental Engineering. Dr. Lohani has been conferred with several Honorary Doctoral degrees including the Degree of Doctor of University by the Griffith University, Australia in recognition of his distinguished contributions to environment. Dr. Lohani was visiting Professor in Tsinghua University, Beijing and also Professor of Tongji University, Shanghai, China.

\section{Professional Background}

Dr. Lohani was Ranking Vice-President of the Asian Development Bank (ADB) for Knowledge Management and Sustainable Development until 30 June 2015. He was responsible for the ADB's Economic Research and Regional Cooperation Department (Office of the Chief Economist), Sustainable Development and Climate Change Department, and Office of Information Systems and Technology.

Prior to assuming his current post, Dr. Lohani was Vice-President (Finance and Administration) of ADB. Dr. Lohani also served as Chair of Investment Committee of the Pension Fund; Chair of Asset Liability Management Committee; and Chair of Crisis Management Committee.

In his almost 30 years in $\mathrm{ADB}$, he has held several positions, including Director General and Chief Compliance Officer of the Regional and Sustainable Development Department (responsible for sectoral and thematic areas like energy, transport, water, urban development, education, environment, gender and governance, and knowledge management), and Special Advisor to the President on Clean Energy, Climate Change and Environment. He had worked in various capacities, mostly infrastructure and sustainable development, environment and climate change. Before joining $\mathrm{ADB}$, he worked for the Government of Nepal (relating to the infrastructure departments) and was Division Chairman of the Environmental Engineering Program at the Asian Institute of Technology (AIT), an independent post-graduate institution located at Bangkok, Thailand.

\section{Present Activities}

Dr. Lohani is the founding President of the Resources Centre (Nepal), and Think Tank member for Confederation of Nepalese Industry (CNI). He is currently Global Head of Climate Change Practice and Distinguished Fellow, Emerging Market Forum, Centennial Group, USA; Distinguished Fellow, Institute for Global Environmental Strategies (IGES), Japan; Distinguished Adjunct faculty and Board of Trustee at Asian Institute of Technology, Bangkok; Special Advisor for the Y-Port Centre, Networking among Cities and Private Firm, The City of Yokohama, Japan; Founding Member and Board of Trustee of Asian Water Council, Korea; International Advisory Panel member, Institute of Water Policy, LKYSPP, Singapore; Board of Governors of UNESCO International Water Security and Sustainable Development, Korea; and External Sustainability Advisory Council member, Ingersoil Rand, USA.

$\mathrm{He}$ has also completed several management development programs, including the Executive Program conducted by the Business School of the University of Chicago, Management Development Program by Cornell University; and programs by Arthur D. Little School of Management, and Corporate Leadership program at Yale University, USA.

Dr. Lohani is an elected member of the National Academy of Engineering (NAE) of United States the highest professional distinction accorded to an engineer - for his work on economic-cum-environment approach to sustainable development. He is a Diplomat of the American Academy of Environmental Engineers (awarded for excellence in the practice of environmental engineering) and is a licensed professional engineer. Dr. Lohani was elected to the rank of AAAS Fellow by the American Association for the Advancement of Science (AAAS) Council for world leadership in development country planning for integrated economic-cumenvironmental sustainable development through protection of natural/social resources. 